\title{
Legal analysis of civil litigation lawyer's fees incorporating into the scope of compensation
}

\author{
Yumin Zhong, Panpan Yu \\ Nanchang Business College of Jiangxi Agricultural University
}

Keywords: Lawyer's fee; Principle of compensation; Risk agent

\begin{abstract}
In a civil lawsuit, can the lawyer's fee be included in a claim to obtain compensation? Although China's current laws are stipulated but too simple, they have not been well implemented in judicial practice. This paper will analyze and discuss the compensation principle, compensation scope and compensation standard, in the hope that it can provide reference for judicial practice.

There are more and more incidents in which citizens hire lawyers to protect their rights, but can lawyer fees be compensated for as litigation claim? What is the compensation standard? At present, although there are several laws and regulations, the specific scope of compensation and compensation standards are not clearly defined, which brings difficulties to the implementation of judicial practice. This article mainly analyzes whether the lawyer's fees should be compensated, the standard of compensation, and the scope of compensation.
\end{abstract}

\section{The definition and characteristics of the lawyer's fee}

\subsection{Definition}

Lawyer fees are labor reward received by a law firm to provide civil litigation services to clients.

\subsection{Characteristics}

(1) There is a law for lawyers to charge lawyer's fees. At present, it is mainly the law of the People's Republic of China and the Measures for the management of lawyers' fees.

(2) There are two forms for charging lawyers' fees: the government guidance price and the market regulation price.

(3) Lawyer's fees must be unified in the name of a law firm, and a formal invoice shall be issued by a law firm.

(4) The lawyer's fee does not belongs to the litigation fee.

\section{Whether the lawyer's fee can be included in the compensation fee}

\subsection{The main reasons for not being able to obtain compensation for legal fees are:}

(1) The lawyer's fee is not a litigation fee and cannot be paied by the losing party.

(2) There is no direct causal relationship between lawyer's fees and civil disputes, and it is not a party's inevitable property loss.

(3) There is no uniform charging standard for lawyers' fees. It is more difficult to determine the reasonable part. In reality, the fees charged by lawyers are basically the agreement between the two parties. If the scope of compensation is placed, there will be overcharging inevitably.

(4) It will lead to an increase in litigation cases and increase the burden on the court. Since the lawyers' fees can be compensated, the number of litigation cases will increase. Owing to limited judicial resources for China, it will greatly increase the workload of the courts, resulting in the abuse of judicial and judicial resources.

\subsection{Reasons for supporting the lawyer's fees can be compensated:}

(1) The expenditure on legal fees has a causal relationship with the other party. If there is no 
dispute, it is no need to hire layers, so the lawyer's fee should be borne by the other party.

(2) Paying lawyer's fees will increase illegal costs, which can constrain people's behavior effectively and reduce the phenomenon infringement and abuse.

(3) Hiring a lawyer to protect their own rights and interests is conducive to the development of a lawyer's career, which can promote the construction of society with the rule of law.

\subsection{We believe that lawyer's fees can be included in the scope of compensation.}

(1) There is a causal relationship between the occurrence of lawyer fees and the other party's illegal activities, which belongs to the indirect property losses of the litigant. Taking infringement disputes as an example, the reason why the litigant hiring a lawyer is that his own rights and interests are infringed, so the litigant need to safeguard their legitimate rights and interests. Therefore, the lawyer's fee has a causal relationship with the the litigant's tort, and naturally belongs to the indirect loss caused by the tort. In 2000, the Shanghai high people's court made a "notice on several specific opinions on the trial of civil cases". In the case of compensation for personal injury, it was proposed that the "lawyer's fee" belongs to the property interests and can be used as a loss in principle.

(2) Compensation for lawyers' fees reflects the principle of fairness and justice in law. Citizens hire lawyers to protect their legitimate rights and interests according to law, which is a manifestation of citizens exercising their rights. At present, the task of the grass-roots courts is serious and the judicial resources are limited, but the state can solve these problems from the point of view of management, but it is impossible to deprive the rights of the litigant from the law. This is contrary to the principle of fairness and justice of the law.

(3) Bringing lawyer's fees into the scope of compensation will enable the litigant's legitimate rights and interests to receive more comprehensive and comprehensive protection.

The goal of our country is to establish a real rule of law society, and the rule of law society must have sound legal system and fine legal standard. For a ordinary citizen who does not have special legal knowledge, it will not protect their rights and interests if they can't hire a lawyer who have the professional legal knowledge and skill. If the lawyer fees can't be compensated, there will be a loss of money even though they win the lawsuit.

(4) It is conducive to the establishment of a harmonious society. The establishment of a harmonious society can't only depends on morality, it must has the strong backing of the law. There are many complaints, indiscriminate complaints, breach of contract and repudiation in civil cases. If the lawyer is hired to win the lawsuit, the lawyer's fee can't be compensated and even the compensation for the compensation can't counteract the lawyer's fee, it will damage the dignity of the law eventually and ultimately destroy the construction of a harmonious society.

\section{Determine the constituent elements of the scope of compensation}

There are some problems in China's current law:(1) there are only a few legal provisions concerning the compensation for lawyers, and the number of civil disputes is insufficient. (2) the scope of compensation and the standard of compensation are not clear. Therefore, it is necessary to determine the components of the scope of compensation.

\subsection{The expenses of the lawyer's fees are real and cause the property losses of the parties.}

Since the lawyer's fee is freely signed by both the law firm and the client, and there is no government or third party participation or supervision, the phenomenon of false lawyer's fees is not excluded. Therefore, the court must first determine the authenticity of the lawyer's fee in the claim.

\subsection{The litigant who is required to pay the lawyer's fee is at fault for the occurrence of the} litigation.

\subsubsection{The behavior of the indemnifying party violates the principle of good faith.}

The principle of good faith is the imperial principle of civil law. If both parties to the dispute can follow this principle, then the dispute will be easily resolved. However, if a party violates the 
principle of good faith and causes litigation, it will need to bear the adverse consequences.

\subsubsection{The act of the indemnifying party is illegal}

The purpose of the parties involved in the lawsuit is to assume responsibility or avoid undue liability. This is the performance of the citizens to exercise their rights. However, if a party improperly defends or abuses a complaint, it is an abusive right, which is an illegal act. So the legal fees incurred should be within the scope of compensation.

\subsection{There is a causal relationship between the expenditure of legal fees and the illegal acts.}

If the other party is required to bear the lawyer's fee paid, the other party's behavior must be illegal. In other words, the other party's illegal behavior causes the party to pay the lawyer's fee. If the other party's behavior is legal, the lawyer's fees paid will not be compensated.

Therefore, if the lawyer's fee is to be compensated, it must meet the above three components, otherwise it will not be included in the scope of compensation.

\section{Compensation standards}

What is the amount of compensation for the lawyer's fees included in the scope of compensation? Is there a standard? There are two main ways for lawyers to charge in China, the government guidance price and the market adjustment price. The market adjustment price is further divided into:(1)charging fixed fee (2)collecting a risk agency fee. This has led to a wide range of lawyer's fees charged by different law firms, even in the same case. Therefore, it is necessary to determine the standard of compensation for different charging methods.

\subsection{The charging way the government guides the price}

In accordance with the provisions of the fifth regulations on the administration of the charge for the service of lawyers, the cases involving the compensation for the lawyer's fee are as follows: (1)civil litigation case; (2)administrative litigation cases;(3)national compensation case;(4)the appeals of the preceding cases. The amount of compensation for these cases must be subject to government-guided prices. At the same time, the sixth rule of the "Measures for the Administration of Lawyers' Fees" stipulates that the benchmark price and the floating range of the government's guidance price shall be formulated by the competent pricing departments of the people's governments of the provinces, autonomous regions, and municipalities directly under the Central Government in conjunction with the judicial administrative departments at the same level, which solves the phenomenon that the actual government guidance price is too low.

China's "Procedures for the Administration of Lawyers' Fees" was issued in 2006. It has been 12 years from now. In judicial practice, many cases have adopted an agreement to determine the fees of lawyers. However, if the lawyers' fees are to be used as compensation claims. When the court determined the compensation standard, the government guidance price must be implemented for compliance with the fifth rule.

\subsection{Market-adjusted price.}

The fifth rule of the Measures for the Administration of Lawyer Service Charges stipulates: The fees for the provision of other legal services by law firms shall be subject to market-adjusted prices; the ninth rule stipulates that fees for lawyer services that are subject to market regulation shall be determined by the law firm and the client. According to the above regulations, there are two ways to adjust the price of the market:

\subsubsection{Fixed fee}

Lawyers charge fixed amount of fees for different cases, which consists of two parts:

(1) Expenses incurred for investigation and evidence collection, such as travel expenses, communication fees, transportation expenses, and evidence collection fees, etc., which are essentially the expenses that the parties should bear, and can be compensated. 
(2) Lawyers' labor expenses, which are strictly legal fees, should be considered in consideration of the working hours of lawyers, the difficulty of legal affairs, the social reputation of the lawyer and the working level on the basis of the government guidance price.

\subsubsection{The fee of risk agency can't be compensated}

The fee of risk agency is an important factor that hinders the lawyer's fees from being compensated. The so-called risk agency fee refers to the fact that if a lawyer wins a lawsuit, he will get a certain percentage of the compensation as a lawyer's fee. The model of risk agent has a semi-risk agent mode and a full risk agent mode.

First, the amount of the risk agent fees is large, and the charging standard is determined arbitrarily. The risk agency fee is agreed by both parties. In addition, 13th rule of the "Administrative Measures for Lawyer Service Charges of the Ministry of Justice" said that "Implementation of Risk Agent Charges, the maximum charge amount may not exceed 30\% of the amount agreed in the fee contract" will result in the lawyer's fee is too high, if the payment is judged, which is inconsistent with the principle of fairness.

Second, the claim for risk agency fees does not comply with the proceedings. This is the main reason why the risk agency fee is compensated. The amount of property damage must be determined before the prosecution, which is a basic requirement of the Civil Procedure Law. The risk agency fee is paid from the compensation received, that is, the amount must be determined after the judgment, so the undetermined fee cannot be included in the claim.

Third, where the contractual compensation is stipulated in the contract, compensation shall be obtained. When the parties sign the contract, they agree that the lawyer's fee can be used as compensation. As long as the agreement between the two parties meets the requirements for the entry into force of the contract, the actual lawyer's fees can be included in the claim.

In summary, the lawyer's fees of civil litigation in China can be compensated in principle, but must be limited in terms of the scope of compensation and the amount of compensation.

\section{References}

[1] Jingfei Liang. 10 cases where the attorney's fees are borne by the losing party, china.findlaw.cn, 2017, 6.

[2] Junbin He, Ronggen $\mathrm{Xu}$. On the necessity of the compensation for the damage of the lawyer's expense [J], Legal System and Society, 2009(35):104+118.

[3] Wenjuan Yin. Who should take the charge of the lawyer's fee [N]. Jiangsu economic newspaper, 2011-05-25(B03).

[4] Xiaodong Kan. Professional non-contentious mediation is an effective safeguard mechanism for insurance consumers-taking the misleading life insurance sales as an example[J].Fujian Finance,2013(04):29-32.

[5] Zhenying Wei, Civil law (7th Edition), Peking University Higher Education Press, 2017.9(255). 